\title{
THE RELATION BETWEEN NASOLACRIMAL DUCT DISEASE AND NASAL DISEASE
}

\section{From the Department of Otorhinolaryngology, Nihon University School of Medicine, Tokyo. (Director: Prof. S. Nakamura)}

By

E. ISHIYAMA M.D., A. AKAO M.D., K. ITO M.D.

\section{AND R. NAKAMURA M.D.}

Two cases of nasolacrimal duct stenosis have been discussed, one case, 23 years of age, female, this is considered to have occured following reop- eration for chronic sinusitis, and the other case, 39 years of age, female, with the stenosis due to the intubation of resin tube in the duct are reported.

\section{鼻添管疾患と鼻疾患との関係}

（特に最近経験せる 2 症例を中心として）

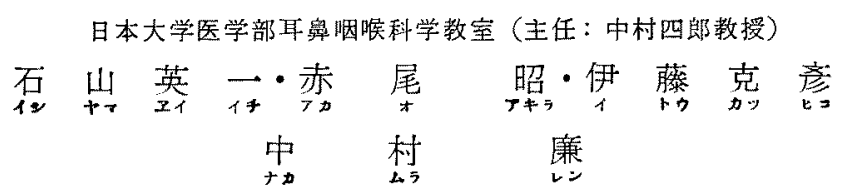

\section{I 緒 言}

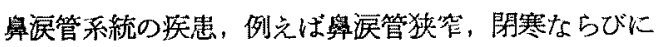
慢性涙等炎などは，眼科的疾患に関逶して扣こる場合の

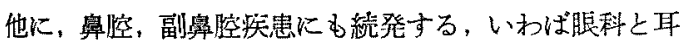

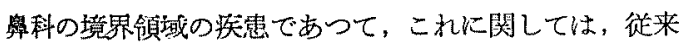
からいろいろと報告されている，我々耳䧹科医は，鼠淚 管の走行殊にこの下鼻道開口部における解剖学的な位置 をばく然とした考えのるとに受け入れている場合が多

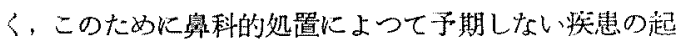
る辌もまた多いるのと考元られる。

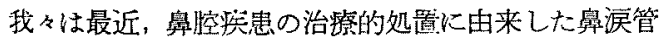

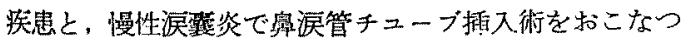
た後に起つた鼻源管閉墨症状を呈した各一例を䌊堅した のでこフに報告する。

\section{II 症例}

註例 (1)

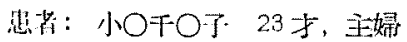

初敦: 昭和 35 年3月15日

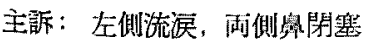

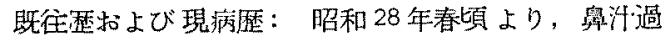
多，両側奥閉塞が次第に強くなり、某耳與科にて慢性副 奥腔炎之骖断され，某病院にて昭和 30 年春雨側副舀腔 開放術を施行し，その後経過は一時的に轻快を示してい たが，昭和 31 年に入つてより，急性增瑟定状が䈐明と

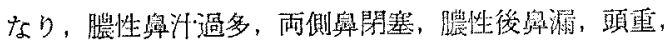
嗅覚減退などが次第に增強してきたので，某病院耳學科

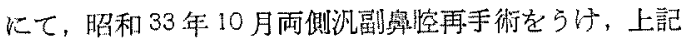
の症状は怪快を示してきたが当科初䜌より6力月前（昭 34年10月始め)より左側流涙を訴克るよらになり, 某

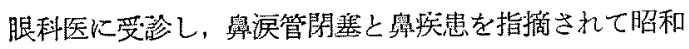
35 年 3 月 15 日当科を受䛦した。

家族迶：特記すべきことなし.

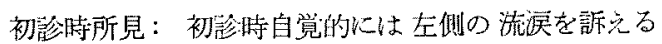

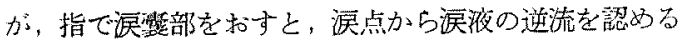
が，流泥以外にはトラコーマその他の扊患圭認めない。

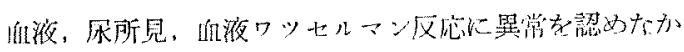
St:

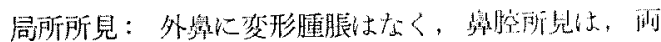


側中鼻道狭く，その間に膿泝を多量に認め，両側中鼻甲 介は鼻茸ように腫脹し，その所見が強く，また下鼻甲介

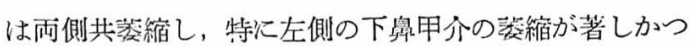
た、しかし, その他の耳, 咽, 喉頭には異常はみられな

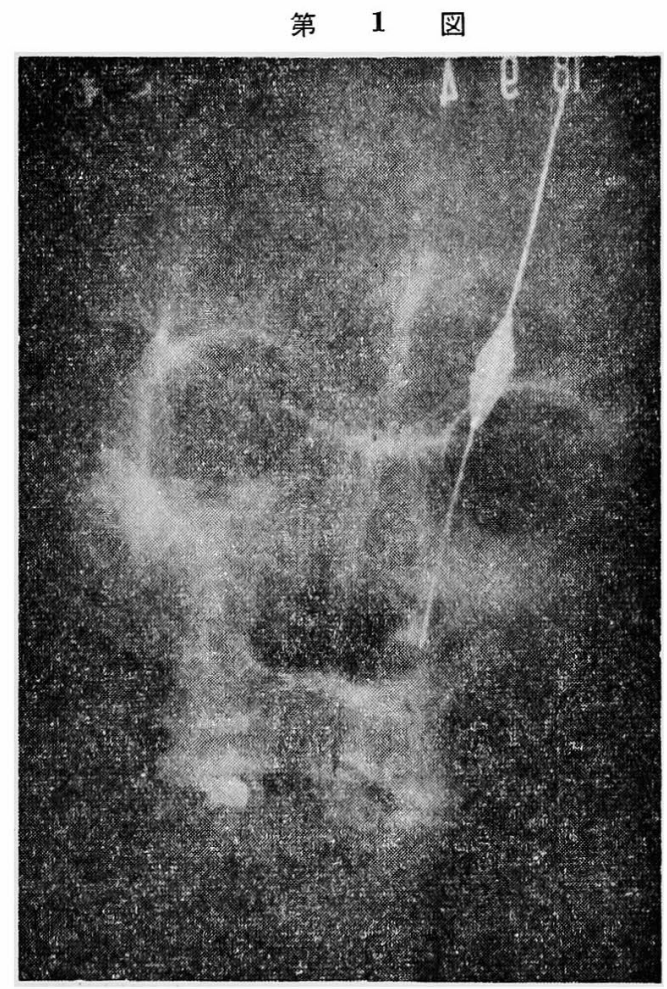

診断：左側術後性 鼻沪管狭窄症と慢性化膿性副鼻腔 炎.

経過：炤和 35 年 3 月 15 日，当科入院の上, 再び左 側副鼻腔開放手術を扣こなつた，その所見は，左上顎洞 顔面壁の前手術孔は捍指頭大で結合組織をもつてお〉わ れ, 洞の残存粘膜は鼻茸様の浮腫状の腫脹を呈し, 粘液 膿性の分泌物少量を認めた。下鼻道の刘孔部は肉来組織 で充満していたが，この肉芽組織を除去するに，下鼻甲 介は前回迄の手術のためによる損傷と推察されるが，下 鼻甲介前端より 5.0〜 $10.0 \mathrm{~mm}$ の部位でその損傷強く, 鼻 甲介胃は一部欠除しており，この部に肉芽組織が 增殖 し, 鸟涙管開口部を閉塞していたので,この部の肉芽組 織を十分に除去した後, 同時に術中, 鼻沃管プジーを通 して，それがよく下鼾道まで通ることをたしかめた。な 和左側の前, 後篩骨洞は, 共に粘膜腫脹し, 化膿性膿沂·を 少量認めたので篩骨洞開放術を同時におこなつた. 術後
かつた，鼻涙管ブジーを通してみたが，鼻涙管下鼻道下 端部で完全に閉塞していた。そのレ線撮影をおこなつた ところ第1図，および第２図の通りである。

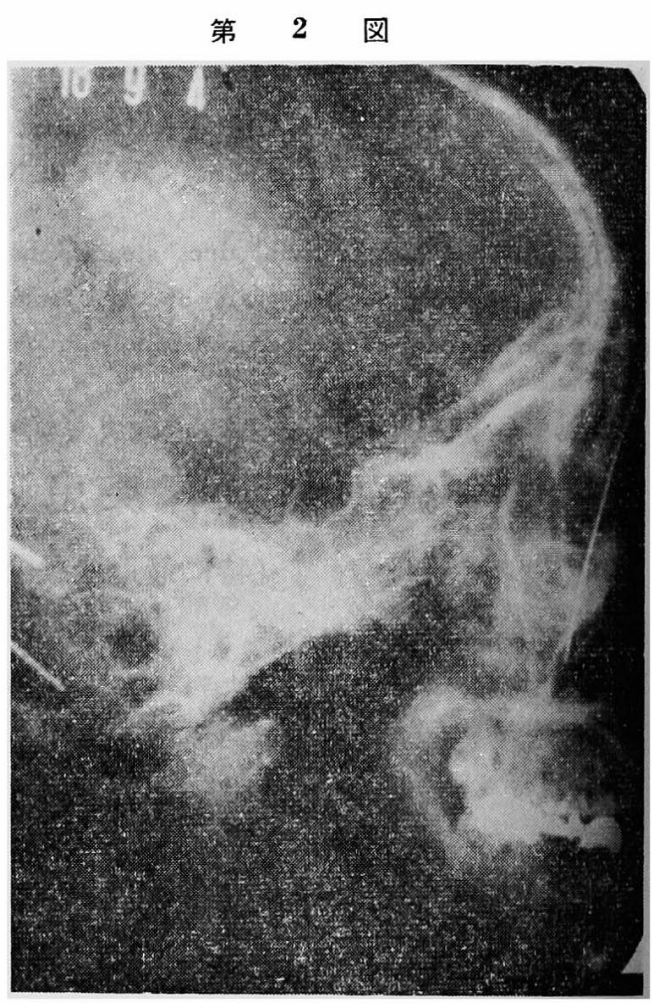

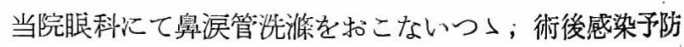
の目的で Cosa-Tetracyn $1000 \mathrm{mg} / \mathrm{lday}$ を 5 日間投与 しつ〉経過を観察したところ, 下鼻道内の肉芽発生もみ られず, 特别の術後感染もなく 4 月 15 日全治退院した. 症例 (2)

患者：駒○貞 $\bigcirc, 39$ 才, 主婦

初䛦：昭和 36 年 8 月 24 日

主訴：右側鼻出血

既住歴：11 年前 (昭和 25 年) Dacryocystit is chronica で右側涙箪部より 鼻涙管にレシンン管の插入術をう け, 2 年前（昭和 34 年）には右乳癌手術を5け今日迄 経過良好である。

現病歴： 5〜6年前 (昭和 30〜31 年頃) より, 将々少 量の右側鼾出血があつたが，最近特に鼻出血は頻回とな り、同側の鼻閉寒を訴えるようになり，詔和 36 年 8 月 24 日当院外来を受㡎した。 
家族歷：特記すべきことなし．

初崄時所見：顔面，頸部などには外見的には異常を 垫めず，血液，尿検查，血液ワッセルマン反応も陰性で あつた．出血時間，凝固時間も正常であつた。

局所所見：外鼻に変形や埂脹などはなく，鼻控所見 は闰側中鼾道および嗅裂には異常を認めず，率中隔左下 部に棘を認めるのみであるが，右下鼻道底部には肉莱様

\section{第 3 図}

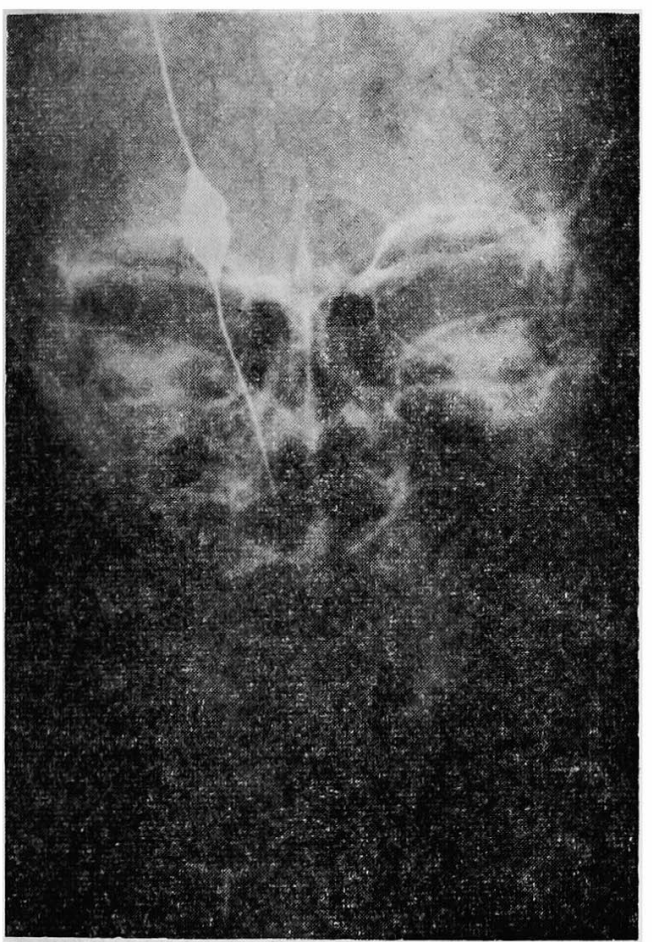

晾断： 右側鼻涙管狭窄症

経過：番腔より，前に鼻涙管に插入されたレジン管 の拔去を外来に执いてこ〉ろみたが，鼻涙管開口部附近 が肉芽で充満していることと，さらに鼻出血強く，かつ 抜去時に抵抗を感ずるためについに拔去出来ず，昭和36 年9月10日入院, Denker 氏法により上顎洞より摘出 術をおこなつた，その時の手術所見は，右上䫟洞の発育 良好で，洞粘膜には特著しい病的所見は認めなかつた が，下鼻道をみると，下番甲介の内側面は下鼻道底部ま で完全に肉莱組織で充満していた，その肉苸組織を十分 に除去してみると，肉芽組織でつまつたレジン管の下端 が下鼻道底部に泌着していた。最初囱涙管ブジーを通し ながらの肉芽除去を考学たが，レジン管内にも肉芽様組
組織が充満し，その一部に凝血塊を附着し，これを触䚷 すると容易に出血する傾向を示した，との他，耳，咽， 啒頭には異常を認めず，また初搒時右結脱にはトラコー マ性瘢痕を認める以外には特別の眼科的所見を認めなか


び第 4 図参照.

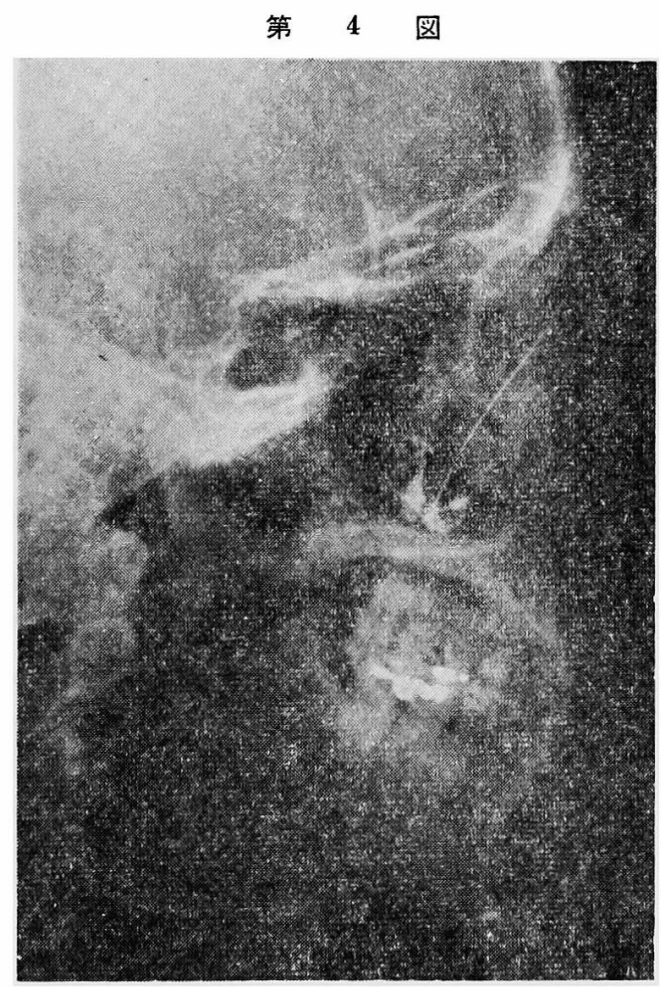

織が充満しているために，鼻腔底部扣よびその周围の十 分な肉苏除去とす〉めていくらちにレジン管亲端部を少 しく破壊したものの，肉芽除去後にレジン管の抜去を招 こなうことができた．摘出されたレジン管は第 5 図のよ うな管であつて鼻腔側の末端部は、レジン管の内腔まで 肉芽によつて充満していた。またその肉芽組織の病理組 織学的所見は第 6 図のごとく単なる炎症性肉帮組織像で 特別の所見はみいだされなかつた，術後腿科にて，沪管ブ ジーを涙点から淚道の中へ注意しつつ插入を批こない， 涙摆洗浄を扣こない同時に, Cosa-Tetracyn $1000 \mathrm{mg} / 1$ day を術後 5 日間感染予防の目的で使用したが術後経 過は良好で, 術後感染もなく昭和 36 年 10 月 2 日退院 し, 以後外来通院全治した. 
第 5 図

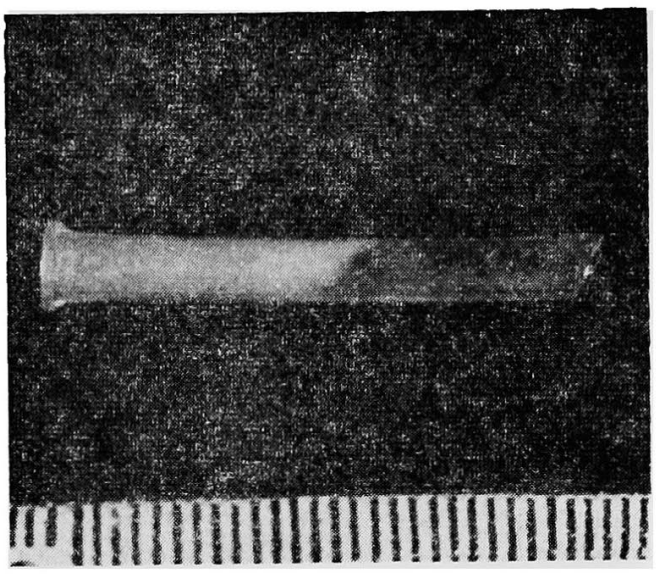

第 6 図

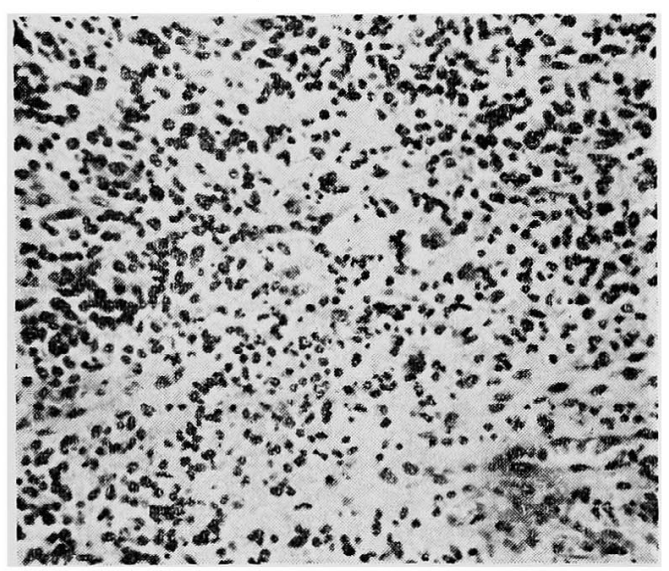

III 考按

鼻涙營狭窄および閉巽をきたす主な原因はトラコーマ と鼻腔疾患である。关の他に先天異常, 外傷, 異物, 綡

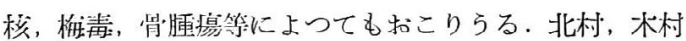
14)は鼻们原因として，奥涙管下部粘慕には全く变化なく とも，下甲介粘膜のポリープ様の增殖，下甲介奥茸ま たは萎縮性鼻炎の班皮などによる 鼻涙管開口部の 閉塞 を，また Rhese 15) の主張する中楀道の变化，すなわち


圧迫をすることによる沪道障害をおこす場合も報告され て扣り，フレルギー性鼻炎，肥厚性鼻炎などによる場合 や，その他結核，梅毒，ジフテリーなど鼻腔と同時に鼻

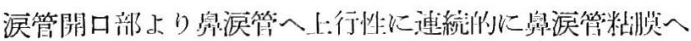

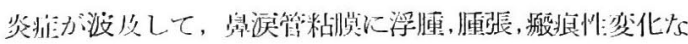
どをおこし，そのために鼠涋管に狄售，閉塞または慢性

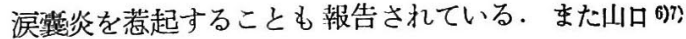
は第 1 表のごとく鼻涙管部の罹患率について発表してい る，下奥道開口部における鼻涙管の罪患率は30.9\%にし

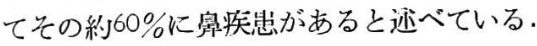

第 1 表（山口による）

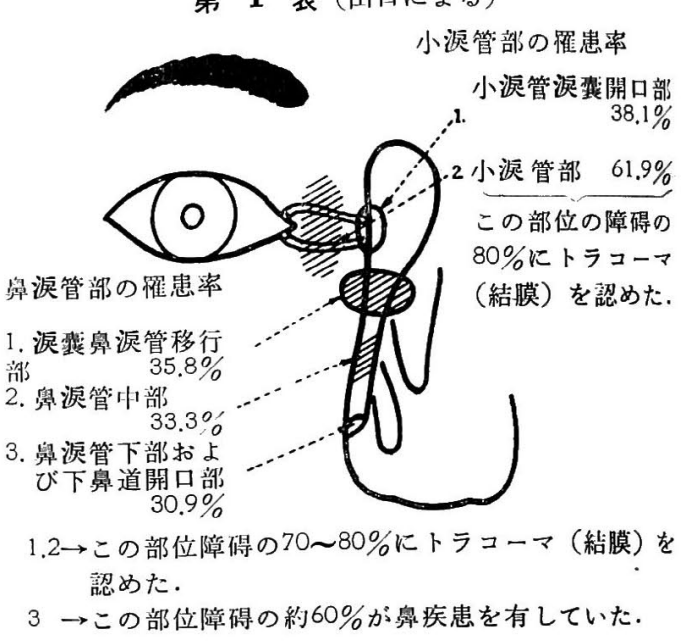

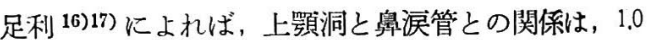
〜1.8mm の䡉芭四に相接しているとの報告があり, また 竹中 18)によれば，鼻涙管下鼻道開口部は平均して，下 鼻甲介附着部の前端より $8.2 \mathrm{~mm}$ 後方で, 鼻腔底より上 方へ約 $6.9 \mathrm{~mm}$, 鼻孔前緑よりは平均 $26.72 \mathrm{~mm}$ (15.5 $39 \mathrm{~mm}$ ) 後方にあり,さらに上顎洞鼻側壁 前端よりは $13 \mathrm{~mm}$ の所より前にあるという研究報告がある.

本拝例を考察するに，本扰例（1）は副鼻腔再手術時 に，䛺涙管下部およびその下゙鼻道開口部を損傷したか， あるいは手術時損傷した下鼻甲介，あるいは対孔形成部 よりの著明な肉芽增殖のために，鼻涙管下鼻道開口部の 閉寒をきたしたものと考えられる。また山口゙が副鼻腔

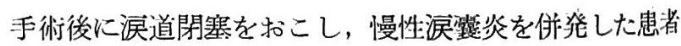
についてしらべた報告では, 早いもので術後 2 カ月から 6 力月, 打そいものでは, 術後約 2 年であつたと述べて いる．また副鼻腔手術に流涙を自覚するようになつた患 者についての報告では，北村99)によれば，手術後2週間 位のものもあつたが，大多数は $1 〜 5$ 力後に，また 3 年後に流涙を訴えた報告もある。本症例（1）では術後 1 年で流涙を訴えている。本症例の経験よりしても副鼻

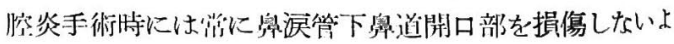
らに特に海意をけらうよらにしなければならない。

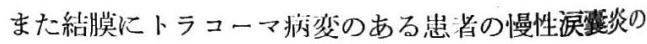




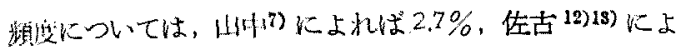
れば6.5\%, Hoffmann》は 4.2\%などの報告があり，ま た阿部，藤非 19) 氏等は涙碳炎の原因としてトラコーマ

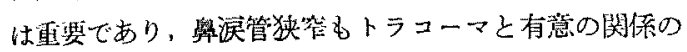

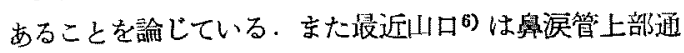

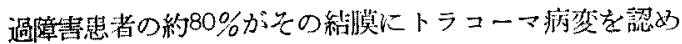

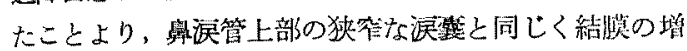

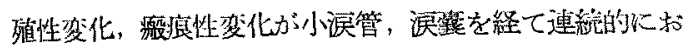
こるのでないかとのベている，本症例 (2) ではかはり トラコーマを原因とせる慢性沃淘炎であるが，昭和 25

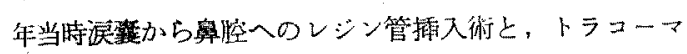
の治著によつて治ゆしていたが，5〜6年前より小量の右 㑡奥出血があり，そのま〉放置していたが，レジ管が

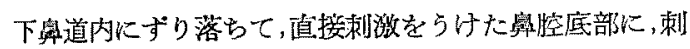

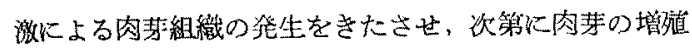
と奥出血をとるならよらになり，鼻涙管の閉基をきたし

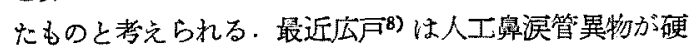
日蓋に穿孔をきたした例を䇉告しているが，いずれにし ても奥涙管に插入される合成樹脂管の長期残留後に問題 があるように考学られる、レジンチニーブ便用の遠腒成 績については現在までのところあまり多くの報告はない が，宮沢 ${ }^{3)}$ に上れば，13例について执こなつた結果，経 過が年以上良好なるもの2 例，1年以上良好なるもの4 例, 不良なるるの 4 例, 天の内 2 例は 1 年以内に摘出, 他の3例では無効であつたとの報告があり，鈴木2 2 は 39 例中 20 例に度好广結果をえたと報告しているが，北 上20121) は Arch. of ophth. 中の論交を写用してレジン チニーブを插入した例でるやはり 2 年以上たつたるのた あまり良好な結果が觉られながたと報告している。

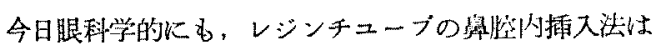

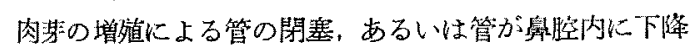
したりすることがあるので閴点が多く，レジンチニー

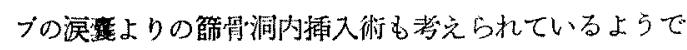

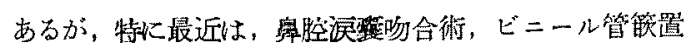
術等が主として挂こなわれている現状のようである。

ダルコサミン添加テトラサイクリン (Cosa-Tetracyn) はテトラサイクリン垍酸掹と比較らると同一量の内服に

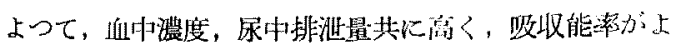

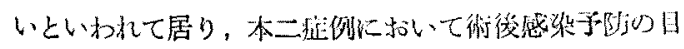

的で使朋したが，内服の子で十分にこの效果をあげるこ とができた。

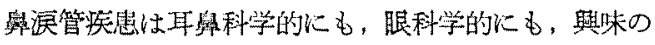
ある境界領域の疾患であり，ことに舆疾患とは関連が滐

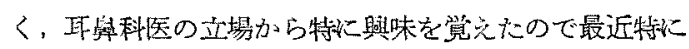
経駺した 2 症例をこつに報告したした゚いである。

\section{IV 結 語}

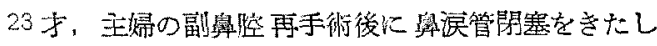
た一例と、39才, 主婦の涙管レジンチューブ择入術後に 発生した率演管閉塞をさたした一例とをそ礼でれ報告

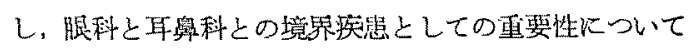
述べ，いささか文献的考察を加党検討した。

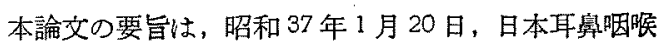
科学会, 関東地方会第 384 回に㨟いて発表した。

\section{文献}

1) 蔡：眼科臨休医報，53, p. 738, 1959。2) 2鈴木：

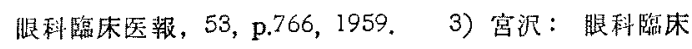

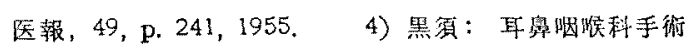
書, p. 372,1961 . 医学珰院発行. 5) 石原：小眼科 学, p.114, 1952. 日本医書発行. 6) 山口：眼科臨 床医報，53，p.993，1959。7) 山口：眼科臨床医報,

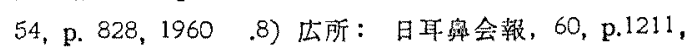
1957.9）北村：日耳率会䀶，59，p. 253，1956.

10）大椅：新眼科手街学，p. $33 ， 1959$.11) 北村：

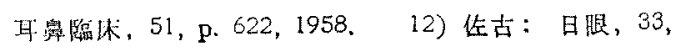
p. 680,1929 . 13) 传古: 日眨, 34, p. 1160,1930.

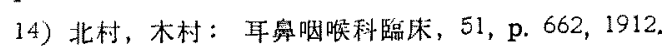

15) Rhese: Deut. med. Wshr.; 8, p. 1646, 1912.

17) 足利：日眼, 25, p. 331,1921 . 17) 足利: 日

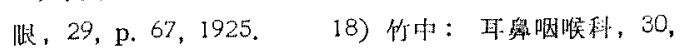

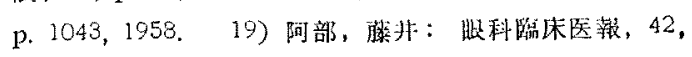

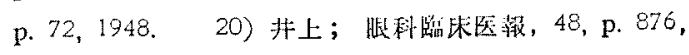

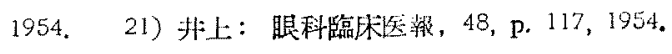

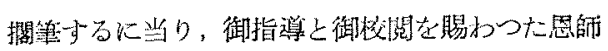
中村四鄀教授に深謝の意を表しまず

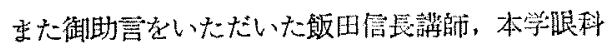

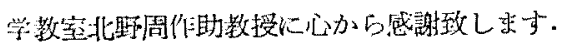

(原稿列着 $=$ 昭和 37.4 .5 日) 